\title{
Is the De-carbonization of Air-transportation to and from the Island of Crete, Greece Feasible?
}

\author{
John Vourdoubas \\ Consultant Engineer, 107B, El. Venizelou str., 73132, Chania, Crete, Greece \\ E-mail: ivourdoubas@gmail.com
}

Received: June 27, $2021 \quad$ Accepted: July 23, $2021 \quad$ Published: July 28, 2021

doi:10.5296/emsd.v10i3.18811～URL: https://doi.org/10.5296/emsd.v10i3.18811

\begin{abstract}
The clean energy transition is an important and urgent issue in European islands contributing in the global effort for climate change mitigation. Island of Crete, Greece is a popular tourist destination while the most of visitors arrive and depart with aircrafts. Aim of the current study is to investigate the possibility of de-carbonizing the air-transportation to and from Crete. Air-transportation has a share at $10.62 \%$ in the total carbon emissions in the island while other studies have estimated higher values. This is higher than the estimated share of carbon emissions in aviation at 2-3\% of the overall carbon emissions worldwide. Various technological and non-technological approaches for de-carbonizing aviation are examined including improvements in aircraft's standards, use of sustainable aviation fuels, offsetting carbon emissions and developing new policies discouraging the frequent use of air travelling. The feasibility and the impacts of these methods are mentioned indicating that de-carbonization is difficult in the short and medium term. Production of sustainable aviation fuels including bio-fuels and electro-fuels in the required quantities and in competitive prices is not foreseen soon. Developing new policies that increase the cost of air travelling and promote alternative sustainable modes in transportation will have undesired impacts in the island's tourism industry. On the contrary de-carbonization in other socio-economic sectors in Crete comprising electricity generation, production of heat and cooling and transportation inside the island is easier than in air-transportation.
\end{abstract}

Keywords: Carbon offsetting, Clean energy transition, Crete-Greece, De-carbonization, Sustainable fuels, Renewable energies

\section{Introduction}

Climate change is the major global environmental problem now days while its mitigation is necessary and urgent. European Union (EU) aims to become carbon neutral by 2050 minimizing the use of fossil fuels and increasing the use of sustainable fuels and energies. 
De-carbonization of various socio-economic sectors can be achieved using different technologies and fuels while the clean energy transition in EU islands is a challenging issue. Tourism industry dominates in Cretan economy contributing at around half of the regional income. The most of tourists visiting the attractive and sunny Mediterranean island every year arrive and depart by airplanes. De-carbonization of air-transportation to and from Crete is necessary for compliance with the EU target regarding future climate neutrality. De-carbonization can be achieved with various ways involving technological and non-technological interventions that are feasible in the short, medium and long term. Zeroing carbon emissions in air-transportation to and from Crete is important for National authorities since it will indicate the required policy measures for achieving the abovementioned goal. It is also important for aviation companies and aircraft's manufacturers regarding the necessary technological changes and the possibilities of producing and using sustainable aviation fuels (SAFs). Current study indicates that de-carbonizing air-transportation to and from Crete is more difficult compared with de-carbonization in other socio-economic sectors in the island.

\section{Literature Survey}

\subsection{De-carbonization in EU Islands}

A draft plan for the clean energy transition in the island of Crete, Greece has been prepared by the region of Crete, Greece, 2020. The plan mentioned that the energy attributed to air-transportation to and from Crete has a share at $29.15 \%$ in the overall energy mix while the carbon emissions attributed to air-transportation to and from Crete have a share at $10.61 \%$ in island's total carbon emissions. A guide navigating the transition towards clean energy in EU islands has been published, 2020. The guide stated that various stakeholder groups according to the quadruple helix model should participate in the clean energy transition. It is also mentioned that energy description in islands should be classified according to the following sectors: a) Electricity generation and consumption, b) Transport inside the island, c) Transport to and from the island, and d) Heating and cooling. A catalogue of good practices for clean energy transition in EU islands has been published, 2019. The report stated that EU islands are pioneer in energy transition for more than 20 years. Islands vary greatly regarding their population, geographic specificities and economic activities. It is stated that their citizens are in the core of the energy transition while various inspiring energy projects are presented. Vourdoubas, 2019 has estimated the carbon emissions due to tourism industry in the island of Crete, Greece. The author stated that the annual carbon emissions were at $488.77 \mathrm{kgCO}_{2}$ per visitor while $80.69 \%$ of them are attributed to international and domestic flights as well as in arrivals and departures by ships. He also mentioned that carbon emissions due to tourism arrivals and departures have a share at $47.74 \%$ in the total carbon emissions in Crete. Vourdoubas, 2020 has examined the role of olive groves in Crete regarding atmospheric carbon removal. The author stated that the area of olive tree plantations in Crete is estimated at 142,900 ha while their annual carbon sequestration is evaluated at $1,310,392$ tonCO $\mathrm{CO}_{2}$. Antequera et al, 2021 have studied the carbon footprint of international air traffic on islands with reference Canary islands, Spain. The authors stated that around 13,500,000 tourists arrive annually at these islands in recent years while the total annual $\mathrm{CO}_{2}$ emissions due to air transportation were at around 6.4 mil. ton. This amount of $\mathrm{CO}_{2}$ emissions is equivalent at 
more than $50 \%$ of the total carbon emissions from the socioeconomic activities in the archipelago.

\subsection{De-carbonization in Aviation}

The evolution of aviation technology and the impacts on climate policy have been examined by Peeters et al, 2016. The authors stated that emissions from aviation will continue to increase in the future although airlines suggest that aviation will become climate neutral. They also mentioned that various "technology myths" regarding low carbon aviation hinder the development of sustainable aviation climate policy. A roadmap for de-carbonizing EU aviation has been published by the European federation for transport and environment, 2018. The proposed measures included: a) Taxation of kerosene at $€ 150$ per tonCO $\mathrm{O}_{2}$, b) Renewal of the fleet achieving lower fuel consumption, and c) Promotion of low carbon emission fuels. The report also mentioned that replacing conventional aviation fuels with electro-fuels would require the generation of large amounts of electricity equal at $28.2 \%$ of Europe's total electricity generation in 2015. Aviation intelligence unit, Euro-control, has issued a paper regarding de-carbonization in aviation, 2019. The report mentioned that de-carbonization in aviation should be based on four pillars including: a) Market based measures, b) Improved technology, c) Improved infrastructure and operations, and d) Sustainable fuels. It is also mentioned that current demand for SAFs is high while the supply at the desired price is very limited. The low-emission technologies for sustainable aviation have been reviewed by Ranasinghe et al, 2019. The authors stated that current advances in aircraft's propulsion engines have small impacts on carbon emissions. They mentioned that technological breakthroughs are required for improving fuel's efficiency and obtaining significant $\mathrm{CO}_{2}$ reductions. The status and prospects of using alternative fuels and electrification in aviation have been studied by Bauen et al, 2020. The authors stated that the use of bio-fuels replacing kerosene is an attractive de-carbonization option. Currently they are produced in low volumes and in high prices. They also mentioned that $\mathrm{H}_{2}$ is an appealing fuel which could be derived from renewable energies (REs) but its use in airplanes requires many changes in their engines and in airports. Small electric aircrafts could be commercially developed soon but deployment of medium and long-haul aircrafts is not foreseen in the short term. The SAFs and their impacts on de-carbonization have been studied by Chiaramonti, 2019. The author stated that large scale deployment of SAFs is a real challenge to day for de-carbonizing aviation. He mentioned that their deployment in large scale requires large investments in production plants, strong reduction in the production cost and investments in quality certification. De-carbonization in various energy critical sectors including aviation has been studied by Sharmina et al, 2021. The authors stated that aviation cannot rapidly cut to zero their $\mathrm{CO}_{2}$ emissions with technological changes only. They mentioned that new policies on the demand side are required. They suggested reduction in frequent air traveling, promotion of low carbon travel modes and promotion of locally produced goods instead of transporting them from long distances. The clean development mechanism (CDM) allowing the offsetting of greenhouse gas (GHG) emissions has been described by Schneider et al, 2009. The author stated that CDM is a zero game to the atmosphere allowing industrialized countries to increase GHG emissions. He proposed an alternative mechanism where only a fraction of 
emissions reduction from CDM projects should be used for GHG emissions offsetting. Becken et al, 2017 have examined the role of offsetting GHG emissions in aviation. The authors stated that airlines offer voluntary carbon offsetting to those customers who wish to mitigate the climate impact of their travel. They also stated that carbon offsetting is a pillar to climate change mitigation in aviation additional to technological changes and possible reductions in air travelling demand. The International and National climate policies for aviation have been reviewed by Larsson et al, 2019. The authors examined various emission mitigating options additional to those proposed by the European emissions trading system (EU-ETS). They stated that additional feasible options include: a) Distance-based air passenger taxes, b) Tax on jet fuel, and c) A quota obligation on bio-fuels.

\subsection{Use of Sustainable Aviation Fuels and Bio-fuels in Aviation}

Rekoske, 2010 has reported on the use of bio-fuels in aviation. The author stated that second generation bio-fuels including waste biomass and oil from algae could be used in aviation. He also mentioned that feedstock availability is important for their production while some hurdles should be overcome. A roadmap for sustainable aviation fuels has been developed by Graham et al, 2011. The authors have studied the possibilities of using the available biomass resources in Australia and New Zealand for production of SAFs based on biomass. They stated that non-food related biomass resources are currently used for heat production, electricity generation and vehicle's fuel production. The future use of biomass resources for SAF production should take into account their competitive uses. The perspectives for sustainable aviation bio-fuels in Brazil have been studied by Cortez et al, 2015. The authors stated that Brazil has a mature industry producing bio-fuels which are broadly used as vehicle's fuels. Substitution of fossil fuels in aviation with bio-fuels is an important challenge in the country taking into account the existing industrial infrastructure regarding bio-fuels production and the availability of various crops. The routes, opportunities and challenges of producing aviation bio-fuels from renewable energy sources (RES) have been examined by Kandaramath Hari et al, 2015. The authors stated that production of bio-fuels for aviation is a highly promising technology substituting petroleum-based fuels. Aviation fuels based on biomass should not be competitive with their use for food production while they should be cost efficient and environmentally friendly. The use of biomass for producing aviation fuels in Australia has been investigated by Murphy et al, 2015. Their study indicated that 5 mil. ton. of biomass per year are required to produce annually $470 \mathrm{ML}$ of aviation fuel within 25 years corresponding at $5 \%$ of the domestic aviation fuel use. The required land for biomass production has been estimated at 1.1 mil. ha. IATA, 2015 has published a roadmap for sustainable aviation fuel. The report stated that three pathways have been already approved for SAF production comprising, a) solid biomass conversion via Fischer-Tropsch process into a mixture of hydrocarbons, b) fatty acids conversion into fuel, and c) sugar conversion to hydrocarbons. It is also mentioned that the opportunities and potential for SAF production are significant but not guaranteed. Braun-Unkhoff et al, 2015 have examined the use of alternative fuels in aviation. The authors stated that all possible fuel candidates should be certified and the raw materials processes, products and properties should be assessed. Use of bio-fuels in Airbus flights for a long period has confirmed that they are at least as good as 
kerosene. The use of electro-fuels replacing conventional fuels in aviation has been studied by Goldmann et al, 2018. The authors mentioned that electro-fuels are using renewable energy in their synthesis while they are carbon neutral. They have studied five potential bio-fuels comprising n-octane, methanol, methane, hydrogen and ammonia stating their advantages and drawbacks. A report regarding SAFs has been published by ICAO, 2018. The report described the different raw materials and the processing routes for SAFs production. The environmental and socioeconomic issues related with their production and the supporting measures for their promotion in aviation are also mentioned. Reliable prescreening tools and procedures for SAFs have been developed by Heyne et al, 2021. The authors stated that appropriate prescreening is required for SAF candidates before entering the official ASTM evaluation process. A multi-criteria-based framework for evaluating SAF production pathways has been developed by Ahmad et al, 2021. The authors examined for every SAF production route the social, technical, economic and environmental impacts. They stated that environmental and economic issues were more important compared to technical and social ones. Huq et al, 2021 have investigated the use of volatile fatty acids derived from wet wastes for producing SAFs. The authors stated that food wastes containing fatty acids could be converted into SAFs which could be blended at $10 \%$ vol. and used as qualified aircrafts' fuel. A fact sheet regarding the use of $\mathrm{H}_{2}$ as a potential low-carbon fuel for aviation has been published by IATA. The report mentioned that aviation is one sector that is difficult to be de-carbonized due to large power requirements of aircrafts. Hydrogen is a potential solution for de-carbonization. Commercialization of large water electrolysis plants based on renewable electricity generating carbon free $\mathrm{H}_{2}$ is foreseen soon. The use of $\mathrm{H}_{2}$ and fuel cells in aviation has been investigated by Baroutaji et al, 2019. The authors stated that kerosene produces 2-3\% of all global $\mathrm{CO}_{2}$ emissions which should be reduced. They mentioned that $\mathrm{H}_{2}$ is considered as a promising alternative clean aviation fuel. The high cost of $\mathrm{H}_{2}$ production via $\mathrm{REs}$, the lack of $\mathrm{H}_{2}$ infrastructure and the need to make changes in aircrafts are currently delaying the deployment of $\mathrm{H}_{2}$ production and use in aviation. A report on $\mathrm{H}_{2}$-powered aviation has been published, 2020. The report stated that $\mathrm{H}_{2}$ combustion can reduce climate impact in flights by $50-75 \%$ while fuel cell propulsion by $75-90 \%$. It is also mentioned that if various technical and economic issues regarding $\mathrm{H}_{2}$ production and use will be solved, $\mathrm{H}_{2}$ propulsion is best suited for short-haul and medium-haul aircrafts.

Aims of the current research are:

a) To estimate the contribution of air-transportation to and from Crete in the overall island's carbon emissions

b) To investigate the possibilities for de-carbonizing air-transportation to and from Crete

c) To compare the easiness of de-carbonizing air-transportation to and from Crete with de-carbonization in the other socioeconomic sectors in the island.

The existing literature is initially surveyed followed by a short description of the tourism industry in Crete and the carbon emissions due to air-transportation to and from the island. Various technological and non-technological methods for de-carbonizing aviation are analyzed. Various aspects in de-carbonization of various sectors in Crete are presented 
followed by the discussion of the findings, the conclusions drawn and some proposals for further work.

\section{Air Transportation to and from Crete}

\subsection{The Tourism Industry in the Island of Crete, Greece}

Tourism is a growing industry in the island of Crete, Greece. It has been estimated that over 5 mil. tourists arrive in Crete every year while the pandemic Covid-19 has reduced sharply the current number of visitors. More than $80 \%$ of them arrive in Crete with international and domestic flights while the expected future growth of tourism in the island, due to its location, will be based on international flights. The share of the income attributed to tourism industry has been evaluated at around $47 \%$ in the annual regional income in Crete. The total number of tourist arrivals in 2016 in Crete have been estimated at 8.56 visitors per local inhabitant while the majority of them are concentrated in the northern coast of Crete. Higher number of tourists could exceed the carrying capacity of the island's ecosystem creating problems of over-tourism and threatening its prosperity and its long-term sustainability.

\subsection{Carbon Emissions due to Air-transportation in Crete}

Current studies regarding the carbon footprint of tourism industry in Crete, in 2016, have indicated that its share in the overall carbon emissions is at $59.19 \%$ while they have been estimated at 3.67 tonCO $\mathrm{CO}_{2}$ per capita (Vourdoubas, 2019). Around $80 \%$ of the tourism-related $\mathrm{CO}_{2}$ emissions are attributed to transportation while the most of them to air-transportation. Arrivals and departures of tourists in the island are mainly based on air-transportation that is responsible for the majority of tourism-related carbon emissions. Other studies regarding carbon emissions in various sectors in Crete comprising electricity generation, heat and cooling production, transportation inside the island and transportation to and from Crete, in 2018 and 2019, have concluded in different results (Personal communication with N. Zografakis, Region of Crete, 2020). They have indicated that although energy consumption in air-transportation to and from Crete has a share at $29.15 \%$ in the total energy consumption in the island the carbon emissions due to air transportation have a share at $10.61 \%$ in the total carbon emissions corresponding at $1.76 \mathrm{tnCO}_{2}$ per capita that is less than $50 \%$ of the emissions estimated in the previous study. The carbon emissions in various socioeconomic sectors in Crete are presented in table 1.

Table 1. Carbon emissions in various socioeconomic sectors in Crete (2018 and 2019)

\begin{tabular}{|l|l|l|}
\hline Sector & Carbon emissions (\%) ${ }^{(1)}$ & Carbon emissions (\%) $^{(2)}$ \\
\hline Electricity generation & 67.55 & \\
\hline Transportation in the island & 10.94 & \\
\hline Air-transportation to and from Crete & 10.62 & \\
\hline Sea-transportation to and from Crete & 9.24 & \\
\hline Transportation by air and sea to and from Crete & 19.86 & 47.74 \\
\hline Heat and cooling production & 1.65 & \\
\hline Total & 100 & \\
\hline
\end{tabular}

${ }^{(1)}$ Source: Personal communication with N. Zografakis, A draft plan for the energy transition in Crete, Greece, Region of Crete, 2020

(2) Vourdoubas, 2019 


\section{De-carbonization in Aviation}

De-carbonization in aviation can be achieved with technological and non-technological methods. The technological methods include the improvement of aircraft's standards and their energy efficiency as well as the production and use of SAFs replacing conventional fossil fuels. The non-technological methods comprise the use of carbon offsetting mechanisms and various new policy measures.

\subsection{Aviation Industry}

Aviation is a growing industry worldwide. As the world is becoming richer people are willing to travel more for leisure and business. Traffic growth is closely linked to GDP growth which is steadily increasing. An increase in passenger's number and in aircraft's fleet has been observed resulting in higher fuel demand in the coming decades in 2030's and 2040's. Over the past forty (40) years aviation has experienced a substantial growth while an average annual increase at around 3-5\% until 2050 is foreseen. The carbon emissions based on aviation are expected to increase while de-carbonization of the sector, due to large power requirements of aircrafts, is rather difficult compared with de-carbonization in other socioeconomic sectors. It is broadly accepted that decrease in carbon emissions in aviation industry is rather difficult in the short term. There is not a consensus among policy makers, international organizations and public authorities regarding the decrease of emissions in the medium and long term since significant changes in the technologies used as well as in present policies for achieving that are required. The necessary technologies for a sharp decrease in carbon emissions are not currently reliable, mature and cost-efficient while the required policies are not easily accepted by the citizens and the aviation companies. Proposals and efforts have been made in improving aircrafts standards and efficiency, in replacing conventional fuels with sustainable low carbon emission fuels, in offsetting carbon emissions using the existing policy instruments and in promoting new policies discouraging the frequent use of aircrafts and selecting alternative, low carbon emission modes of transportation.

\subsection{Improving Aircrafts Standards}

Decrease in carbon emissions can be achieved with improvements in aircrafts. This can be obtained with: a) Renewal of the existing aviation fleet with new airplanes with optimized design and higher energy efficiencies, b) Improving the aircraft's propulsion engines consuming less fuel. This, though, will have small impacts on carbon emissions. Major breakthroughs are required in propulsion engines for achieving major impacts on carbon emissions that are not foreseen in the short term, c) Use of electric aircrafts. Manufacturing of aircrafts for short distances is feasible with the current status of technology. Manufacturing of electric aircrafts for medium and long-haul is not foreseen in the short term.

\subsection{Sustainable Aviation Fuels}

Kerosene can be replaced in aircrafts with SAFs which are not based on fossil fuels comprising: a) Bio-fuels that can be produced by solid biomass, fatty acids and sugars. The technology of bio-oil's production is well known but improvements regarding the cost of production are needed in order to promote their use in aircrafts. Cultivation of biomass 


\section{Macrothink}

producing the quantities of bio-fuels needed in aviation requires large areas of land. This could result in land competition between food and SAF production that is not desirable, b) $\mathrm{H}_{2}$ that is produced by water electrolysis powered by REs, and c) Electro-fuels that are using REs for their production and they are carbon neutral comprising n-octane, methanol, methane, and $\mathrm{NH}_{3}$. Current demand for SAFs is high while their supply at the desired price is limited. Bio-fuels is an attractive option for replacing kerosene while their use in Airbus flights has confirmed their suitability. $\mathrm{H}_{2}$ is a desired fuel particularly when it is produced by REs. Its use requires major changes in infrastructure regarding $\mathrm{H}_{2}$ storage and transportation that are not currently available. Technology improvements are also needed for reducing its production cost. Carbon emissions reduction is higher when $\mathrm{H}_{2}$ is used with fuel cells in electric aircrafts compared to its use by combustion.

\subsection{Offsetting Carbon Emissions}

Carbon emissions offsetting in aviation can be achieved using the clean development mechanism (CDM) under the Kyoto protocol that allows crediting GHG emissions reduction from the implementation of carbon abatement projects in developing countries. Various airlines offer voluntary carbon offsetting to those customers who wish to decrease or totally eliminate their carbon footprint during their flights. CDM is an offsetting tool with zero sum impacts into the atmosphere regarding GHG emissions. It can be considered as a complementary mechanism for reducing the impacts of aviation on climate change.

\subsection{Policy Changes}

Various policy measures have been proposed for decreasing the impacts of aviation on climate change. These include: a) A quota obligation on bio-fuels in aviation, b) Distance-based air passenger taxes, c) Taxing jet fuels, and d) Annual limitation on air travelling per passenger and promotion of alternative travelling modes. These policy measures are going to discourage the use of aircrafts either by increasing the cost of air travelling or by imposing limitations on air transportation that are not easily accepted. These policy measures though can assist in the decrease of GHG emissions in aviation. Various options for de-carbonizing aviation are presented in table 2. 
Table 2. Various options for de-carbonizing aviation

\begin{tabular}{|c|c|c|}
\hline De-carbonization option & Result & Feasibility \\
\hline $\begin{array}{l}\text { Improving aircraft's } \\
\text { standards }\end{array}$ & $\begin{array}{l}\text { Relative low decrease of carbon } \\
\text { emissions }\end{array}$ & $\begin{array}{l}\text { Requires technical breakthroughs in the } \\
\text { design of engines and aircrafts }\end{array}$ \\
\hline $\begin{array}{l}\text { Use of SAFs including } \\
\text { bio-fuels and electro-fuels }\end{array}$ & $\begin{array}{l}\text { Total elimination of carbon } \\
\text { emissions can be achieved }\end{array}$ & $\begin{array}{l}\text { There are problems related with land } \\
\text { availability regarding biomass cultivation } \\
\text { for production of the required quantities of } \\
\text { bio-fuels. Production of electro-fuels } \\
\text { including } \mathrm{H}_{2} \text { is currently not cost } \\
\text { competitive }\end{array}$ \\
\hline $\begin{array}{l}\text { Offsetting } \quad \text { carbon } \\
\text { emissions }\end{array}$ & $\begin{array}{l}\text { Carbon emissions are not reduced. } \\
\text { They are offset with atmospheric } \\
\text { carbon removal }\end{array}$ & They can be easily used \\
\hline $\begin{array}{l}\text { Policy changes - quota on } \\
\text { bio-fuels }\end{array}$ & Reduce carbon emissions & They can be easily used \\
\hline $\begin{array}{l}\text { Policy changes - kerosene } \\
\text { taxation }\end{array}$ & $\begin{array}{l}\text { Increases the cost of air } \\
\text { transportation reducing } \\
\text { demand for air-travelling }\end{array}$ & They can be easily used \\
\hline $\begin{array}{l}\text { Policy changes - taxation } \\
\text { based on miles }\end{array}$ & $\begin{array}{l}\text { Increases the cost of air } \\
\text { transportation reducing } \\
\text { demand for air-travelling }\end{array}$ & They can be easily used \\
\hline
\end{tabular}

Source: Own estimations

\section{Comparing De-carbonization of Air-transportation to and from Crete with De-carbonization in other Sectors}

Significant de-carbonization in air transportation to and from Crete is not feasible in the short and medium term. The use of bio-fuels and electro-fuels coupled with offsetting current carbon emissions from aircrafts as well as various new policy measures that have been proposed could achieve a small reduction in carbon emissions in short term. De-carbonization in the long term requires significant technology improvements and policy changes. Production of SAFs in Crete is not currently feasible and cost-efficient while the use of carbon emission offsetting mechanisms and innovative policy measures are not used in local and regional scale for achieving this goal. De-carbonization of the electricity generation sector in Crete could be more easily obtained promoting the rich solar and wind energy resources in the island with solar photovoltaic systems and wind farms. De-carbonization of the heating and cooling sector is also more easily achievable. De-carbonization of transportation in the island could be obtained in the medium and long-term replacing the use of conventional fuels in vehicles with zero carbon fuels like bio-fuels, electricity or $\mathrm{H}_{2}$. Bio-fuels are not produced in Crete while the use of electric cars with fuel cells powered by $\mathrm{H}_{2}$ is not cost-efficient. Electricity generation using REs in Crete is cost-efficient and combined with electric cars equipped with re-chargeable batteries could de-carbonize, in the medium and long term, the transportation inside the island. Comparison of de-carbonization in various sectors in Crete is presented in table 3. 
Table 3. Comparison of de-carbonization in various sectors in Crete

\begin{tabular}{|l|l|l|}
\hline Sector & Changes required for de-carbonization & $\begin{array}{l}\text { Is de-carbonization technically and } \\
\text { economically feasible? }\end{array}$ \\
\hline Electricity generation & $\begin{array}{l}\text { Interconnection of the electric grids of Crete } \\
\text { and continental Greece is required } \\
\text { New investments in solar-PV systems and } \\
\text { wind farms are required }\end{array}$ & Yes, it is feasible in the medium term \\
\hline $\begin{array}{l}\text { Heat and cooling } \\
\text { production }\end{array}$ & $\begin{array}{l}\text { Interconnection of the electric grids of Crete } \\
\text { and continental Greece is required } \\
\text { Replacement of fossil fuels with REs } \\
\text { combined with the use of electric heating } \\
\text { and cooling systems }\end{array}$ & Yes, it is feasible in the medium term \\
\hline $\begin{array}{l}\text { Transportation inside } \\
\text { the island }\end{array}$ & $\begin{array}{l}\text { Use of electric cars with re-chargeable } \\
\text { batteries powered with renewable electricity } \\
\text { support. It is feasible in the medium } \\
\text { and long term }\end{array}$ \\
\hline $\begin{array}{l}\text { Air-transportation to } \\
\text { and from Crete }\end{array}$ & $\begin{array}{l}\text { Technological and non-technological } \\
\text { changes are required }\end{array}$ & $\begin{array}{l}\text { Major changes are required. They are } \\
\text { not feasible in the short or medium } \\
\text { term }\end{array}$ \\
\hline
\end{tabular}

Source: Own estimations

\section{Discussion}

Our findings indicate that zeroing carbon emissions in air-transportation to and from Crete can be achieved either with technological changes including the design of more energy efficient aircrafts and the production and use of SAFs or with non-technological changes comprising carbon emissions offsetting and development of new policies. However de-carbonization of air-transportation to and from Crete is not technologically and economically feasible in the short term. A significant difference regarding the estimation of carbon emissions in air-transportation to and from Crete has been reported. The draft plan for the energy transition in Crete, Greece, 2020 has stated that the share of carbon emissions related to air-transportation is at $10.61 \%$ of the total carbon emissions in the island while the share of carbon emissions due to both air and sea transportation is at $19.86 \%$. Vourdoubas, 2019 has estimated the share of air and maritime transportation at $47.74 \%$. Antequera et al, 2021 have estimated the share of carbon emissions due to air-transportation to and from Canary islands, Spain at more than $50 \%$ of the total carbon emissions in the archipelago. Current results reveal the areas and sectors that more efforts should be made for decreasing carbon emissions. Production of bio-fuels replacing kerosene requires large areas of land for biomass production which could be also used for the production of foodstuff. Biomass use in aviation is also competitive with its other uses for heat and energy generation as well as for production of vehicle's fuels. Production of electro-fuels requires large amounts of electricity and investments in large benign energy systems generating renewable electricity. They do not though indicate the details that technological progress and non-technological interventions can be achieved in order to lower the climate impact of air-transportation to and from Crete. They do not examine the possibility of producing bio-fuels or electro-fuels in Crete for replacing kerosene. Future work should be focused on the estimation of the necessary bio-fuels and $\mathrm{H}_{2}$ replacing kerosene in air-transportation to and from Crete. Further more in 
the estimation of the size of the required solar-PV plants and wind farms for electrolytic $\mathrm{H}_{2}$ production replacing kerosene. It should be also focused on estimating the size of the required clean development projects that should be implemented in developing countries, according to Kyoto protocol, for offsetting the carbon emissions due to air-transportation to and from Crete.

\section{Conclusions}

Mitigation of climate change requires the decrease of atmospheric carbon emissions in all sectors while EU is aiming in zeroing its carbon footprint by 2050. De-carbonization of air-transportation to and from Crete has been investigated. Although international aviation contributes at around $2-3 \%$ in the global carbon emissions this percentage is significantly higher in tourism dominated islands like Crete where the most visitors arrive and depart with aircrafts. Air-transportation has a share at around $10.62 \%$ in total carbon emissions in the island that is significantly higher than the global average. De-carbonization of air transportation in Crete can be achieved with technological and non-technological interventions including: a) Improvements in energy efficiency of aircrafts, b) Replacement of kerosene with low or zero carbon emission fuels comprising bio-fuels, electro-fuels and $\mathrm{H}_{2}, \mathrm{c}$ ) Offsetting carbon emissions with the existing policy instruments, and d) Creating new policy measures discouraging air-travelling. The required technological improvements regarding low emission aircrafts and SAFs as well as the difficulties in developing new realistic and acceptable policies do not facilitate the decrease of carbon emissions in aviation shortly. De-carbonization of air-transportation to and from Crete in the short and medium term is more difficult compared with de-carbonization in other socio-economic sectors in the island including electricity generation, heat and cooling production and transportation inside the island.

\section{References}

Ahmad, S., Ouenniche, J., Kolosz, B. W., Greening, Ph., Andresen, J. M., Maroto-Valer, M. M., \& Xu, B. (2021). A stakeholders' participatory approach to multi-criteria assessment of sustainable aviation fuels production pathways. International Journal of Production Economics, 238, 108156. https://doi.org/10.1016/j.ijpe.2021.108156

Baroutagi, A., Wilberforce, T., Ramadan, M., \& Ghani Olabi, A. (2019). Comprehensive investigation on hydrogen and fuel cell technology in the aviation and aerospace sectors. Renewable and Sustainable Energy Reviews, 106, 31-40.

https://doi.org/10.1016/j.rser.2019.02.022

Bauen, A., Bitossi, N., German, L., Harris, A., \& Leow, K. (2020). Sustainable aviation fuels, Status, challenges and prospects of drop-in liquid fuels, hydrogen and electrification in aviation. Johnson Matthey Technology Review, 64(3), 263-278.

https://doi.org/10.1595/205651320X15816756012040

Becken, S., \& Mackey, B. (2017). What role for offsetting aviation greenhouse gas emissions in a deep-cut carbon world? Journal of Air Transport Management, 63, 71-83.

https://doi.org/10.1016/j.jairtraman.2017.05.009 
Braun-Unkhoff, M., \& Riedel, U. (2015). Alternative fuels in aviation. CEAS Aeronautical Journal, 6(1), 83-93. https://doi.org/10.1007/s13272-014-0131-2

Chiaramonti, D. (2019). Sustainable aviation fuels: the challenges of de-carbonization. Energy Procedia, 158, 1202-1207. https://doi.org/10.1016/j.egypro.2019.01.308

Cortez, L. A. B., Nigro, F. E. B., Nogueira, L. A. H., Nassar, A. M., Chantarelle, H., ... Baldassin, R. (2015). Perspectives for sustainable aviation bio-fuels in Brazil. International Journal of Aerospace Engineering. https://doi.org/10.1155/2015/264898

Dorta Antequera, P., Diaz Pacheco, J., Lopez Diez, A., \& Bethencourt Herrera, C. (2021). Tourism, transport and climate change: The carbon footprint of international air traffic on islands. Sustainability, 13, 1795. https://doi.org/10.3390/su13041795

EU islands in the energy transition, A catalogue of good practices. (2019). Clean Energy for EU islands. [Online] Available:

https://euislands.eu/sites/default/files/eu_islands_good_practice_IA.pdf

Goldmann, A., Sauter, W., Oettinger, M., Kluge, T., Schroder, U., Seume, J. R., Friedrichs, J., \& Dinkelacker, F. (2018). A study on electro-fuels in aviation. Energies, 11, 392. https://doi.org/10.3390/en11020392

Graham, P., Reedman, L., Rodriguez, L., Raison, J., Braid, A., ... O'Connell, D. (2011). Sustainable aviation fuels roadmap: Data assumptions and modeling, Centre of Policy Studies, National Research Flagships. [Online] Available:

https://algaebiomass.org/wp-content/uploads/2010/06/AVIATI2.pdf

Heyne, J., Ranch, B., Le Clercq, P., \& Colket, M. (2021). Sustainable aviation fuel prescreening tools and procedures. Fuel, 290, 120004.

https://doi.org/10.1016/j.fuel.2020.120004

Huq, N. A., Hafenstine, G. R., Huo, X., Nguyen, H., Tifft, S. M., ... Vardon, D. R. (2021). Toward net-zero sustainable aviation fuel with wet waste-derived volatile fatty acids. PNAS, 118(13), e2023008118. https://doi.org/10.1073/pnas.2023008118

Hydrogen-powered aviation. A fact-based study of hydrogen technology, economics and climate impact by 2050. (2020). Fuel cells and hydrogen joint undertaking, Clean Sky2. [Online] Available:

https://www.fch.europa.eu/sites/default/files/FCH\%20Docs/20200507_Hydrogen\%20Powere d\%20Aviation\%20report_FINAL\%20web\%20\%28ID\%208706035\%29.pdf

Islands transition handbook, how to develop your island's clean energy transition agenda. (2020). Clean Energy for EU islands. [Online] Available: https://www.euislands.eu/sites/defa ult/files/2019-10/eu_islands_transition\%20handbook_IA_web.pdf

Kandalama Hari, Th., Yaacob, Z., \& Binitha, N. N. (2015). Aviation bio-fuel from renewable resources: Routes, opportunities and challenges. Renewable and Sustainable Energy Reviews, 42, 1234-1244. https://doi.org/10.1016/j.rser.2014.10.095 


\section{Macrothink}

Environmental Management and Sustainable Development

ISSN 2164-7682

2021, Vol. 10, No. 3

Larsson, J., Elofsson, A., Sterner, Th., \& Akerman, J. (2019). International and National climate policies for aviation: a review. Climate Policy, 19(6), 787-799.

https://doi.org/10.1080/14693062.2018.1562871

Liquid hydrogen as a potential low-carbon fuel for aviation. (2020). Fact Sheet 7, IATA. [Online] Available: https://www.iata.org/contentassets/d13875e9ed784f75bac90f000760e998 /fact_sheet7-hydrogen-fact-sheet_072020.pdf

Murphy, H. I., O’Connell, D. A., Raison, R. J., Warden, A. C., Booth, T. H., ... Rye, L. (2015). Biomass production for sustainable aviation fuels: A regional case study in Queensland. Renewable and Sustainable Energy Reviews, 44, 738-750.

https://doi.org/10.1016/j.rser.2015.01.012

Peeters, P., Higham, J., Kutzner, D., Cohen, S., \& Gossling, S. (2016). Are technology myths stalling aviation climate policy? Transportation Research Part: D. Transport and Environment, 44, 30-42. https://doi.org/10.1016/j.trd.2016.02.004

Personal communication with N. Zografakis, Region of Crete. (2020). A draft plan for the energy transition in Crete, Greece.

Ranasinghe, K., Guan, K., Gardi, A., \& Sabatini, R. (2019). Review of advanced low-emission technologies for sustainable aviation. Energy, 188.

https://doi.org/10.1016/j.energy.2019.115945

Rechose, J. (2010). Sustainable aviation fuels. PPT presentation in Farnborough Air Show. pp. $2-10$.

Roadmap to De-carbonizing European Aviation. (2018). European Federation for Transport and Environment. [Online] Available: https://www.transportenvironment.org/sites/te/files/pub lications/2018_10_Aviation_decarbonisation_paper_final.pdf

Schneider, L. (2009). A clean development mechanism with global atmospheric benefits for a post-2012 climate regime. International Environmental Agreements, 9, 95-111.

https://doi.org/10.1007/s10784-009-9095-9

Sharmina, M., Edelenbosch, O. Y., Wilson, C., Freeman, R., Gernaat, D. E. H. J., ... Le Quere, C. (2021). De-carbonizing the critical sectors of aviation, shipping road freight and industry to limit warming to $1.5-2^{\circ} \mathrm{C}$. Climate Policy, $21(40), 455-474$.

https://doi.org/10.1080/14693062.2020.1831430

Sustainable Aviation Fuels Guide. (2018). International Civil Aviation Organization. [Online] Available: https://www.icao.int/environmental-protection/knowledge-sharing/Docs/Sustaina ble\%20Aviation\%20Fuels\%20Guide_vf.pdf

Sustainable Aviation Fuel Roadmap, IATA. (2015). [Online] Available:

https://www.iata.org/contentassets/462587e388e749eeb040df4dfdf02cb1/2015-report-alternat ive-fuels.pdf

The aviation network - De-carbonization issues, Think paper 4. (2019). Aviation Intelligence 


\section{Macrothink \\ Environmental Management and Sustainable Development \\ ISSN 2164-7682 2021, Vol. 10, No. 3}

Unit, Euro-control. [Online] Available:

https://www.eurocontrol.int/sites/default/files/2020-01/eurocontrol-think-paper-4-decarbonisa tion-en.pdf

Vourdoubas, J. (2019). Estimations of carbon emissions due to tourism in the island of Crete, Greece. Journal of Tourism and Hospitality Management, 7(2), 24-32.

https://doi.org/10.15640/jthm.v7n2a3

Vourdoubas, J. (2020). Estimation of carbon sequestration from olive tree groves in the island of Crete, Greece. International Journal of Agriculture and Environmental Research, 6(4), 553-565.

\section{Copyright Disclaimer}

Copyright for this article is retained by the author(s), with first publication rights granted to the journal.

This is an open-access article distributed under the terms and conditions of the Creative Commons Attribution license (http://creativecommons.org/licenses/by/4.0/). 